\title{
Lapurdum
}

Euskal ikerketen aldizkaria | Revue d'études basques |

Revista de estudios vascos | Basque studies review

Numéro spécial 3 | 2015

Euskal hizkera eta dialektoak gaur egun

\section{J. Duvoisin On Kixote Mantxakoari ekinez. Itzulpen zirriborroa.}

\section{Oroitz Jauregi}

\section{(2) OpenEdition \\ Journals}

Édition électronique

URL : http://journals.openedition.org/lapurdum/2663

DOI : 10.4000/lapurdum.2663

ISSN : 1965-0655

\section{Éditeur}

IKER

Édition imprimée

Date de publication : 1 novembre 2015

Pagination : 177-205

ISBN : 9782955341322

ISSN : $1273-3830$

Référence électronique

Oroitz Jauregi, « J. Duvoisin On Kixote Mantxakoari ekinez. Itzulpen zirriborroa. », Lapurdum [Linean], Numéro spécial 3 | 2015, Sarean emana----an 12 juillet 2017, kontsultatu 01 mai 2019. URL : http:// journals.openedition.org/lapurdum/2663 ; DOI : 10.4000/lapurdum.2663 


\section{J. Duvoisin On Kixote Mantxakoari ekinez. Itzulpen zirriborroa.}

Oroitz JAUREGI

Euskal Herriko Unibertsitatea (UPV-EHU)

\section{Laburpena}

Artikuluan Jean Duvoisinek (1810-1891) egindako Miguel de Cervantes-en (1547-1616) Don Quijote de la Mancha (1605) lan erraldoiaren euskarazko itzulpen saioa biltzen da, sarrera eta lehenengo hiru kapituluen itzulpen saioa, hain zuzen ere. Eskuizkribuak eman dakigukeen informazioagatik, itzulpen zirriborrotzat hartu dugu, ez amaierako bertsiotzat; horregatik, edizio lan honen helburua da itzulpen prozesua islatzea, J. Duvoisinek eskuartean izandako itzulpen aukeren berri ematea, eta ez soilik amaierako testua.

\section{Sarrera $^{1}$}

Antze handitako Aitorenseme don Kichote Mantchakoaren gerthakiariak don Miguel de Cervantes Saavedrak erdaraz ezarriak Duvoisin Kapitainak eskararat itzuliak izenburua duen itzulpen lanaren argitalpena da eskuartean duguna, Don Kixoteren hitzaurreko sarrera eta

1. Eskerrak eman nahi nizkioke Joseba Lakarrari lan honetan zehar, hasiera urrunetik bukatu arte emandako laguntzagatik. 
darraizkion hiru kapituluek osatzen dutena, hain zuzen ere. Itzulpen testu honen argitalpena berritzailea da moduagatik, ez baita Jean Duvoisinen (1810-1891) itzulpen lan hau argitaratzen den lehen aldia, XX. mende hasieran izan zituelako argitalpenak. Aldiz, lehen aldia da eskuizkribuan agertzen den gisan argitaratzen dena, ondoren aipatzen den arrazoiagatik. Duvoisinek testua eskuizkribu gisa gorde zuen, baina dirudienez, ez zen itzulpen lana amaitutzat emanda gorde zuen testuaren behin-betiko bertsioa. Hala ere, ez dirudi bertsio berriagorik egin zuenik. Hemen argitaratzen den edizioaren ezaugarria da zirriborroa izatea, amaitugabeko bertsioa, beraz. Izan ere, testu nagusian bertan ezabatutako hitz eta esaldi ugari ageri dira, eta horiekin batera badira oharrak aldamenetan, hots berarentzako grafia anitzak eta bestelako ezaugarriak testu amaigabe bat dela salatzen dutenak.

Testuaren ezaugarri horrek erakargarri egin lezake hizkuntzalaritzaren alor desberdinetan. Testuan, adierazi nahi denaren sintaxi, morfologia zein hiztegi mailako zalantzak, hautuak eta alboan utzitako aukerak agertzen direnez, egokiera eskaintzen du Duvoisinek zein adierazmolderen alde egin zuen ikusteko. Alde honetatik, testuaren aukera aberastasuna azpimarra liteke. Itzulpengintzaren aldetik ere interesgarri izan daiteke, azken batean, itzulpen baten nolabaiteko barne prozesua erakusten digulako, testua nola sortua izan den agerian utziz.

Egia da testuaren zirriborro izatea hasierako atalean hobe antzematen dela, testua aurreratu ahala, irakurketa errazagoa baita, letra garbiagoz idatzia dagoelako, eta ezabatutako hitzak zein esaldiak ere urritzen direlako. Hala ere, testua osotasunean hartuta, zirriborrotzat hartzen jarrai dezakegu.

\section{Duvoisin itzultzaile}

Ez da harritzekoa Jean Duvoisin ainhoarra itzulpen lanekin lotzea, itzulpen lan anitzen sortzaile baitugu lanbidez aduanetako kapitain izandakoa. J. Haristoy-ren "Le Capitaine Duvoisin et ses travaux" artikuloari begirada bat eman besterik ez dago egindako lanak ugariak eta oparoak izan zirela baieztatzeko, eta ez soilik itzulpengintza arloan. ${ }^{2}$ Egindako itzulpen ugarien kalitatea ikusita, batek baino gehiagok esan du Duvoisin euskal itzulpengintzaren aitzindari argia izan dela, Mitxelenak (1988) "Euskal itzultzaileen buruzagi eta errege" izendatu zuen.

Duvoisin ezaguna da, batez ere Bonaparte printzearen berriemaile izan zelako. Aldiz, Bonaparte printzea ezagutu baino lehenagokoa da euskara eta euskal gaiekiko maitasuna eta ardura. Halaxe esan daiteke, Bonaparte printzea 1856an ezagutu baitzuen eta 1830 inguruan, Duvoisinek 20 urte inguru zituela, aduanetan langile zelarik, hasi baitzen Telemakeren abenturak itzultzen. 1856an, Bonaparte ezagutu zuen urte berean, Liburu ederra argitaratu zuen arren, pentsa daiteke aurreko urte(eta)ko lanaren emaitza izan zela.

2. Duvoisin kapitainaren lan oparoen berri jakin nahi duenari J. Haristoy-ren lana irakurtzea gomendatzen zaio. 
Duvoisinen lanetan pisu handiena itzulpenek dutela adierazi dugu eta itzulpen horien artean bat azpimarratu beharra dago, Bible Sainduarena. Aurretik baziren Biblia zatiak itzulita, lehenago Testamendu Berriak izan baitzituen euskal ordainak, Leizarragaren (1571) eta Haranederren (1855) eskutik, baina Duvoisinena izan zen Biblia osoa euskaraz egindako lehen itzulpena. Horregatik aparteko garrantzia hartzen du euskal literaturan. Bonaparte printzearen aginduz sortutako lana 1859 eta 1865 bitartean Londresen argitaratu zen.

Itzulpenak ez zituen beste hizkuntza batetik euskarara egiten soilik, beste euskalki batetik berera, lapurterara ere itzuli zuen. Esaterako, Duvoisinek 1856an Liburu ederra izena eman zion liburua aita Kardaberazen Aita San Ignazioren egerzizioak afektoakin liburuaren lapurterazko bertsioa da. Gertaera hau egun bitxia gerta badakiguke ere, ez dirudi hain harrigarria zenik orain dela mende bat.

\section{On Kixoteren itzulpenaren ibilbidea}

Eskuartean dugun itzulpena On kixoteren sarrera eta lehen hiru atalak soilik itzuliak izateak ez du agian lagundu lana ezagutarazten. ${ }^{3}$ Baina esan behar da behin baino gehiagotan argitaratu zela XX. mende hasieran. Edward Spencer Dodgsonek 1904ean formato desberdinetako bi argitalpen egin zituen, bata liburu formatoan, Ernest Seitz-en inprimategian 100 ale argitaratu ziren, eta bestea Le Pays Basque-Eskual Herria aldizkarian zatika argitaratu zen, 1904ko ekainaren 4, 11, 18, 25 eta uztailaren 2an.

J. Apraiz-ek ere bitan argitaratu zuen Duvoisinen itzulpena 1905ean On kixoteren argitalpenaren hirugarren mendeurrena betetzen zela eta euskaraz egindako itzulpenak jasoaz eginiko omenaldi liburuan, ondoko izenburuarekin Donkituera umill euskalduna Cervantes-eri opatua Manchako don Quijote, seme argi ta ospatsua agertu zanetik irugarren eunki-urrunean.

Duvoisinen eskuizkribuak lehenengo aldiz argitara bitartean egindako ibilbidearen nondik norakoa E.S. Dodgson-ek argitaratutako liburuxkatik atera dezakegu, amaieran, testuaren ondoren Arturo Campionek E.S. Dodgsoni bidalitako eskutitz baten transkripzioa baitator, eta bertan adierazten da eskuizkribua Duvoisinek A. Campioni oparitu ziola, eta era berean, A. Campionek E.S. Dodgsoni eskuizkribua helarazi ziola, berak argitaratu zezakeelakoan. Ibilbidea Pariseko Biblioteque Nationale-n amaitzen da, han gordetzen baita.

Atal honen hasieran esan dugu itzulpenaren ezaugarri nagusia izan daitekeela eskuizkribua zirriborroa izatea, edo amaigabea behintzat. Hala ere, Campioni opari egiteko, Duvoisinek eskuizkribua nahiko egintzat edo landutzat zeukala ere pentsa daiteke, baina ez dugu froga garbirik hori baieztatzeko. Hipotesi honen alde egingo luke lehenago esan bezala, sarreraren itzulpenean ondoko hiru ataletan baino askoz ere zuzenketa eta ezabatze gutxiago

3. On Kixoteren euskarazko lehen itzulpen osoa Pedro Berrondo apaizak egin zuen, bi alditan argitaratu zelarik, 1976an eta 1985ean. 
izatea. Baina hala eta guztiz ere, osorik harturik, ez dirudi amai-amaierako bertsioa dugunik eskuartean.

Eskuizkribuan amaieran bada nota bitxi bat, sur la demande de un Coronal espagnol ipintzen duena. ${ }^{4}$ Oharraren arabera, eskuartean dugun itzulpena espainiar koronel baten aginduz egindako itzulpena dela pentsa daiteke. Espainiar militar hori nor izan zitekeen arakatzen hasi eta 1923ko maiatzaren leko El Pueblo Vasco. Diario Independiente Donostian argitaratutako aldizkarian G. de Zumuarreguik Cultura Vasca atalean idatziriko "El Quijote en vascuence" izeneko artikuluak eta J. Apraizen edizioen sarreran irakurritakoak erabat argitzen du zalantza. Francisco López de Fabra koronel Cervantes zaleak, 1870-1880 inguruan, On Kixotek Sancho Panzari emaniko lehen kontseiluak (bigarren zatiko XLII kapitulua) ehun hizkuntzetara itzultzeko agindua eman omen zuen. Baina militar hau bere ametsa gauzatu baino lehen hil zen, 1880an, 25 hizkuntzetako itzulpenak bilduak zituelarik. Tartean ez zen euskarazko itzulpenik.

Ohar hau eskuizkribuarekin batera topatzeak zenbait zalantza azaleratzen ditu: Lopez Fabrak agindu ote zion On kixoteren itzulpen osoa Duvoisini? Izan ere Duvoisinen itzulpena sarrera eta darraizkion hiru kapituluk osatzen dute, eta hasiera-hasieratik hasteak pentsaraz lezake itzulpen osoa zuela Duvoisinek buruan, baina arrazoiak arrazoi ez zuela bukatu. Beste aukera bat litzateke Duvoisinek López Fabrak agindutako kapituluaren itzulpena egin izana, baina ez dirudi hala izan zenik. Esan bezala, López Fabrak bigarren liburuko XLII. atalari dagozkion itzulpenak bildu zituenez, pentsa daiteke atal hori ere itzuli ahal izan zezakeela Duvoisinek, eskuizkribuarekin batera dagoen oharrari kasu eginez. Aldiz, ez dirudi hala izan zenik. Aurreko ahapaldian aipatutako G. de Zumuarreguiren lanean López Fabrak agindutako XLII kapituluaren euskarazko itzulpenaren aipamena egiten da, lapurterara egindako itzulpenaren aipamena, hain zuzen ere. Bertan adierazten da egilea ezezaguna izateaz gain, J. Vinson-en ustearen arabera ez litzatekeela Duvoisin izango itzulpenaren egilea, baina ez du beste xehetasunik ematen. Hari honi jarraituz, M. Torres-ek (2005) argitaratutako lanean López Fabra koronelak agindutako lanei buruzko xehetasunak ematen dituenean, euskarazko bi itzulpen aipatzen dira, adieraziz bata iparraldeko euskaraz eta bestea hegoaldeko euskaraz idatzita daudela, eta argitaratutako urtea, 1941, eta lekua ere azaltzen dira. Madrileko Biblioteca Nacionalen behintzat gordetzen diren argitalpen horien aleetako sarreran adierazten da itzulpenen egileak zein izan ziren, iparraldeko euskarara itzulitakoa Délgue izeneko abadea eta hegoaldeko euskarara itzulitakoa P. Manuel Antonio de Antia Urnietako erretorea izan zirela irakur daiteke. Ez zebilen oker, beraz, J. Vinson iparraldeko euskarara egindako itzulpenaren egiletzat aduanetako kapitaina hartu ez zuenean. Patri Urkizuk ere, 2004ko lanean jasotzen du Kixotearen bigarren liburuko XLII kapituluaren itzulpenaren erreferentzia. Artikuluan irakur daiteke 1882an argitaratu zela lau orrialdeko lantxoa, non argitaratu zen adierazi gabe, baina Urkizuk Baiona edo Biarritz aldea izan zitekeela dio. Urkizuk galdutzat ematen duen itzulpen hau aldiz, ez dago galdua eta hurrengo argitalpen batean emango da bere berri.

4. Dodgson-en edizioan azalean bertan dator aipamen bera. 


\section{Edizioa}

Esan dugu eskuizkribuak Duvoisinengandik abiatuta egindako ibilbidean A. Campion izan zuela hurrengo jabea, oparitu egin baitzion, eta ondoren A. Campionek E. S. Dodgson-i eman ziola On Kixoteren argitalpenaren mendeurrena gerturatzen ari zenez, argitara zezakelakoan. E. S. Dodgsonek eskuizkribuaren kopia bat egin ostean Pariseko Bibliotheque Nationalera bidali zuen, eta hantxe dago, Fondo Basque-Celtan, 130 signaturapean. Informazio hau guztia E.S. Dodgson-ek egindako liburuxkako edizio amaieran jasotzen diren bi gutunetan irakur daiteke. Eskuartean dugun edizioa egiteko UPV/EHUko Koldo Mitxelena liburutegiko faksimila erabili da.

Edizio honen helburua testuaren beraren bizitza agertzea denez, oin-oharretan jasoko dira egileak testua osatzerakoan albora utzi dituen aukerak, horiek ere informazio oparoa eta aberasgarria eskaini dezaketelakoan. Edizioaren izaeragatik, testu nagusia eskuizkribuan agertzen den moduan ahalik eta gehien mantentzeko saiakera egin da.

Edizio honetarako grafia aldaketa gutxi egin dira. $<x>$ grafia era horretara adierazteaz gain, beste grafia mota batez ere adierazten dela esan daiteke, nolabait ere eskuinaldeko bi muturrak lotuz egindakoa. Badira zenbait hitz $<x>$ rekin soilik adierazten direnak, beste zenbait aipatutako zeinuarekin, eta badira zenbait hitz bi grafia horiekin adierazten direnak: hauxi, axegin, onxa eta abar, horregatik grafia beraren aldaeratzat har daitezke. Oro har gaur egun $<\mathrm{ts}>$ grafiarekin adierazten ditugun hitzak lirateke era honetara adierazitakoak. Hala ere badira zenbait hitz berezi, $<x>$ grafiaz adierazten direnak, gaur egun ere grafia modu horretara emango genituzkeenak, esaterako Xenofon eta Alexander.

Grafia kontuekin jarraituz, aipagarria da itzulpeneko pertsonaia nagusiaren izena ere grafia desberdinez adierazten duela, Kijote, Kichote, Kikote eta Kikore ere bai, nahiz eta lehenengoa den gehienetan erabiltzen duena. Beste aldaerak bere horretan utzi dira. Gainontzeko grafiak ere dauden-daudenean utzi dira. Paragrafoen banaketa ere Duvoisinen testuan bezala mantendu dira.

Edizioan oin-oharretan ematen dira testuan ezabatuta ageri diren hitz zein esaldiak, azken batean albora utzitako aukerak. Gehienetan irakur daitezkeen arren alde batera utzitako aukerak, beste zenbaitetan ez da hala izan, eta ezin irakur daitekeela adierazi da. Horrelakoetan [ ] erabili dira. Bestetzuetan, faksimilaren egoeragatik, lerro amaierako zein hasierako azken edo hasierako hizki zein hitzak ongi irakurri ezin izan direnean, Dodgson-en lana baliogarria izan da ezin irakurriak osatzeko

Gerta daiteke, zenbaitetan testu nagusia gramatika aldetik zuzena ez izatea, edo akatsen bat izatea, baina edizio honen helburua dagoen dagoenean ematea denez, bere horretan utzi da.

Dodgson-en edizioan testu nagusian egindako aldaketak ez kontuan hartzea erabaki da ondoko arrazoiengatik. Dodgson-en edizioko oin oharrei begiratzen badiegu, badira zenbait Duvoisinen testuan aldaketa eragiten dutenak, Dodgson-i testua ulertzen lagun dezaketela iruditzen zaiolako. Aldiz, aldaketa horietako zenbait Dodgson-ek erratak direlakoan egindako 
zuzenketak dira, baina, ez dirudi beharrik zegoenik aldatzeko, horietako zenbait etzirelako akatsak. Halaxe dio Urkizuk $(2004,206)$ aldaketa horiei buruz bere argitalpenean "es evidente para un nativo de la lengua vasca, que la forma primitiva no necesitaba ninguna corrección. Menos mal que las notas de Dodgson nos muestran cómo era el original". Beraz, aldaketa horiek aintzat ez hartzearen aldeko apustua egin da.

Dodgson-en edizioan aurki daitezkeen oin-oharrak aipagai dituen bitxikeria bat ekarri nahi nuke. Le Pays Basque-Eskual Herria aldizkarian 1904ean agertutako edizioa Dodgson-ek egindako edizioa dela esan dezakegu baina aldizkarirako moldatua, lau zatitan argitaratua 1904eko ekain-uztailetan. Baieztapen honen zergatia litzateke liburuko oin-oharrak eta aldizkarikoak berdinak izatea. Aldizkarian agertutako lehen aldian, ekainaren 4ko aldian, Dodgson-ek oin-ohar bat ipintzen du, liburuxkako 9. orrialdean agertzen dena, esanez Landerreche abadeak dioela esaldi baten egitura ez dela garbia. Aldizkariaren hurrengo argitalpenean, ekainaren 11 koan, testuaren itzulpena, Campionen eskutitz bat eta Dodgson nor zen adierazten duen testuaren ondoren Landerretxe abadearen beraren oharra jasotzen da, bere burua zuritu nahian, esanez, Dodgsonen oin-oharrean zenbait akats daudela. 


\title{
Antze handitako Aitorenseme don Kichote Mantchakoaren gerthakiariak don Miguel de Cervantes Saavedrak erdaraz ezarriak \\ Duvoisin Kapitainak eskararat itzuliak
}

\begin{abstract}
Aintzin-Solasa
Irakurle astiduna, sinhexiko bide nauzu, ${ }^{5}$ nik juramentu egin gabe nahi nukeela liburu hau, ${ }^{6}$ ene ${ }^{7}$ burutik atheratua den bezala, izan ${ }^{8}$ badadi ditakeen ederrena, gogaragarriena eta izpirituxuena; ai bainan ${ }^{9}$ ezin $^{10}$ hauxi dut munduko legea ${ }^{11}$ zeinak nahi baitu mundutar ${ }^{12}$ bakhotchak athera detzan bere iduriko umeak. Eta holetan inolako umea athera zezakeen ene izpiritu agor eta guti ${ }^{13}$ ikasiak, non-ez ume kizkor, kozkor eta moldagaitz bat, ${ }^{14}$ nihork egundaino ${ }^{15}$ bururatu etzaizkon asmu eta gogoetaz bethea: hitz batez ${ }^{16}$ athera ${ }^{17}$ ditakeen bezalakoa presoindegi batean non ere facheria guziek baitaukate beren ${ }^{18}$ bilkhua, non ere lelo ${ }^{19}$ tcharrek egiten baitute beren egoitza? Pausuak, bakezko tokiak, kampo bazterretako gozoak, zeruetako $^{20}$ garbitasunak, ithurrietako gargara emeak ${ }^{21}$, gogoko deskanxuak egiten ohi dute izpiritu agorrenak agertzen direla urgoi eta mundura ematen dituztela ume batzu guzien ${ }^{22}$ bozgarri eta zoragarri direnak. Aita bati gertha badakio seme bat ixusia eta moldegabea, ${ }^{23}$ bere haurra-
\end{abstract}

5. Ondoren tatxatuta: zer egin dezadan galdatu gabe erraten badarotzut

6. Ondoren ongi irakurtzen ez den zerbait tatxatua

7. Ondoren tatxatuta: izpirituaren ume

8. Ondoren ongi irakurtzen ez diren bi hitz tatxatuak. Lehenengoa dadin izan daiteke, bigarrena ezin irakur daiteke. Ustezko dadinen gainean badadi dago zuzendua. Bigarren hitzaren gainean ditakeen eta azpian nihon den formak agertzen dira. Bietarik bat nahikoa da. Pentsa daiteke Duvoisinek ez zuela erabaki bi forma hauen artean, eta bi aukerak mantendu zituela, aldiz hemen bakarra jarri dugu testu nagusian.

9. Ondoren tatxatuta: ezin [-]

10. Ondoren tatxatua: eragin dut

11. Hitz amaieran tatxatuta: -ri

12. Ondoren tatxatuta: iduri guziak egin detzalla

13. Ondoren tatxatuta: heziak

14. Ondoren tatxatuta: eta

15. Ondoren tatxatuta: asmatu ez dituen bezalako ustekeriaz bethea

16. Ondoren tatxatuta: presondegi batean

17. Ondoren tatxatuta: baititake

18. Ondoren tatxatuta: egoitza

19. Ondoren tatxatuta: beltzenek

20. Ondoren tatxatuta: zuetako

21. Ondoren ongi irakurtzen ez den zerbait tatxatua

22. Ondoren tatxatuta: zoragarri

23. Ondoren tatxatuta: amodioak 
rentzat duen amodioak ezartzen dio begietan bela bat ez dadin ohart haren ${ }^{24}$ bageri, bainan har detzan hobeki zerbait maithagarri eta pompochik balire bezala, eta bere adiskideeri aipha detzoten $^{25}$, hala nola izpirituko chorginkeria ${ }^{26}$ pollit batzu. Nik ordean, iduri ${ }^{27}$ badut ere don Kikoten aita naizela, haren aitaizuna naiz; ez dut $^{28}$ egin nahi arronteko gisara, ez-eta, irakurle maitea, bertze asko bezala zure ganat ethorri, hurran nigarra begietan ${ }^{29}$, zure othoiztera barkha detzatzu ${ }^{30}$ edo aitzakiaz estal nerea delako haur horren baithan ikhusiko ditutzun erratekoak. Etzarenaz geroz ez horren ahaide ez adiskide, zure baithan zure arima daukazunaz geroz hain libro nola ${ }^{31}$ burua-gorenik daukanak zure etchean jaun zarenaz geroz, errege bere zuzenetan bezain ongi, eta dakizunaz geroz erran zaharra: Ene kapapetik hiltzen dut errege; —horiek orok salbu eta libro egiten zaituzte ene alderako egimbide eta zorretarik, eta holetan kondaira huntaz erran dezazuke iduritzen zaitzun guzia ${ }^{32}$ beldurrik gabe ${ }^{33}$ b[ide]gaberik ${ }^{34}$ hel dakizun huntaz erranen duzun gaizkitik ez eta sari zerbait erran dezakezun ongitik.

Bakharrik, nahi nautzukeen eman garbi eta has-hasa, aintzin solas baten edergailurik gabe, eta liburueri hastapenetan ezartzen ohi zaizkoten ardurako soneteria, epigrameria eta ${ }^{35}$ laudoriozko espantueriaririk ${ }^{36}$ gabe. Alabainan ${ }^{37}$ nahiz lan zerbait eman darotan hunen chuchentzeak aithortzeko dut batere ez dudala handiagorik kausitu, orai irakurtzen duzun aintzin solas hunen egitea baino. Askotan eskurat hartu izan dut luma hunen izkribatzeko eta askotan utzi ezjakinez zer iskriba. Bainan behin, nindagolarik duda-mudetan, papera aintzinean hedatua, luma beharri artean, ukhondoa mahainean eta burua eskuaren gainerat emana, gogoetaka hean zer erran behar nuen, hor heldu zait adiskide bat, gizon gozo eta ongi aditzen dena. Eta harek, ikusterarekin ni hain gogoetaxu, galdatzen darot zer ariaz; eta nik ez bainion gorde nahi ${ }^{38}$, ihardesten diot, buruan nerakilkala don Kikoten liburuari ezartzeko nuen aintzin solasa, eta halako lanetan ematen ninduela, non ez bainuen egin nahi eta hain guti argitarat atheratu halako zaldun noblearen egintza harrigarriak.

24. Ondoren tatxatuta: eskasei

25. Hitz honetan -tzo- bi aldiz agertzen da, bata bestearen jarraian. Bigarrena tatxatua dago.

26. Ondoren tatxatuta: eta

27. Hitz amaieran tatxatuta: -rik

28. Ondoren tatxatuta: $\operatorname{arront}[\ldots]$

29. Ondoren tatxatuta: bezala

30. Ondoren tatxatuta: haur

31. Ondoren tatxatuta: gizonik

32. Ondoren tatxatuta: bideg dana zerbaiten

33. Ondoren tatxatuta: zerbait bidegabe

34. Eskuizkribuan $b[\ldots]$ gaberik irakur daiteke; baina aurreko tatxaduran zerbait bidegabe ipintzen duenez, suposa daiteke hemen ere hala behar duela.

35. Ondoren tatxatuta: espantueri

36. Lerro amaieran espantueriari- dago, eta falta zuen $-k$ idazteko lekurik ez zuenez, hurrengo lerroan hasten da; baina - $k$ hutsa jarri beharrean silaba osoa -rik errepikatzen du.

37. Ondoren tatxatuta: aitortzeko dut

38. Ondoren tatxatuta: erraten 
«Alabainan, nerrakion ¿nola nahi duzu ez nadin khecha jendea deitzen den legemaile zaharrak erasiko duenaz ikhustearekin, hambat urthez ichilik eta ahantzia lo egotu naizen ondoan, orai guzien aintzinera agertzen naizela, ene urthe guziak bizkarrean, ihi zaharra bezain agorra den kondaira batekin, kondaira asmu hixeko, tcharkitto chuchendua, atheraldi on guti eta jakitaterik batere ez duena, izan gabe ez plama bazterretan ez liburuaren akhabantzan, nihon ere argitasunik ${ }^{39}$, nola ikusten ditudan ${ }^{40}{ }^{41}$ bertze liburuak, nahiz ${ }^{42}$ elhe chahar eta harroz ${ }^{43}$ eginak, hain ongi betheak direla Aristotelesen, Platonen eta filosofoeria guziaren $e^{e r r a n e} z^{44}$, non ederresten baitituzte irakurleak, eta hauek baitauzkate hekien egileak gizon ${ }^{45}$ eskolatu, argitu eta ederki mintzatzen direnentzat ? ¡Eta oraino, zer ez da Iskritura Saindua aiphatzen dutenean! ¿nor ez lezake erran san Thomas batzu direla, Elizako dotor batzu, hortaz mintzo direnean hain chothiltasun beiratuarekin non ${ }^{46}$ erakuxi ondoan andrekari galdu bat lerro batean ${ }^{47}$, berehala bertzean egiten baitute predikutto jainkotiar bat zeinaren aditzea eta irakurtzea axegin eta gozo bat baita ${ }^{48}$ ? Ene liburuak horiek oro eskas izanen ditu, zeren ez baitut zer argitasun ezar ez plama bazterretan ez guziaren akhabantzan. Hain guti ez dakit ere zein autorri narraikion ene liburuan ${ }^{49}$ hastapenean ${ }^{50}$ izenen ezartzeko, bertze guziek egiten duten bezala, A B C eta letra guzieri jarraikiz ${ }^{51}$, Aristotelesen ganik ${ }^{52}$ hasirik eta ${ }^{53}$ akhabatuz Xenofonen baithan edo bertzela Zoiloren edo Zeuxisen baithan, nahiz baita izan zadin mihi gaichto bat eta bertzea pintatzaile bat. Halaber ${ }^{54}$ sonetaz hastapenean eskas izanen da ene liburua, edo bederen duke, markis, konde andre handi ${ }^{55}$ aphezpiku ${ }^{56}$ edo berxulari ospe handitakoek egin sonetaz; nahiz galda banetzote bizpahirur adiskide ofizioko direneri, eman lakizkitedala segur naiz, eta hala holakoak non ${ }^{57}$ gure Espainia huntan gehienik aiphatzen diren ${ }^{58}$ berxularienak ez bailitaske heyen bardineko.

39. Ondoren tatxatuta: bertze liburuetan

40. Bi forma daude eskuizkribuan, baititut eta ditudan, eta ez dago bietariko bat ere tatxatua. Suposa daiteke, beraz, autoreak aukeran utzi zituela, oraindik erabaki finkorik hartzeke.

41. Ondoren tatxatuta: bezala

42. Ondoren tatxatuta: izan ditezen

43 Ondoren tatxatuta: betheak

44. Ondoren ongi irakurtzen ez den zerbait tatxatua.

45. Ondoren tatxatuta: argitu

46. Ondoren tatxatuta: lerro batean

47. Ondoren tatxatuta: bertze

48. Ondoren tatxatuta: $H$

49. Ondoren tatxatuta: haren

50. Ondoren ongi irakurtzen ez den zerbait ezabatua.

51. Ondoren tatxatuta: hasirik

52. Ondoren tatxatuta: et Xenofonen ba[..]

53. Ondoren tatxatuta: Xenofonen

54. Ondoren tatxatua: eskas iz

55. Ondoren tatxatuta: eta

56. Hitz honetatik hasita tatxatuta: -ek egin sonetaz

57. Ondoren tatxatuta: ez baitetzaskete halakorik egin

58. Ondoren tatxatuta: berxulariek ez bailezak 
Guzien buru, ene adiskide jauna, gogoari eman diot utzi behar dela Don Kikote jauna Mantchako bere liburutegian ehortzia, Jainkoak igor dezon arteo ${ }^{59}$ horrembertze gauza eskas dituenez nork ederztatuko duen; ezik ez daukat heyen chuchentzeko gai ene burua, ene ahal eta jakitate chumeen gatik, eta zeren ethorkiz herabe eta nagi bainaiz liburuetan bilhatzera zer-ere neronek baitakit erraten heyen beharrik gabe. Hortarik dathortzi ene baithan aurkhitu ditutzun duda-muda eta gogoetak, aski baita eneganik aditu duzunaz ${ }^{60}$ heyetan sarthua ene uzteko.

Solas horiek aditu ${ }^{61}$ eta ene adiskideak eskuaz jotzen du kopeta eta irri zabal bat eginez erraten darot: Ala Jainkoa! anaya, orai khentzen darotazu ustekeria bat ene baithan zena zu ezagutzen zaitudan aspaldiko ${ }^{62}$ urthetarik hunat ${ }^{63}$. Gizon zuhur eta umo batentzat iduki zaitut bethi zure eginkari orotan. Bainan oraikoan ikusten dut halakoa izatetik hain urrun zarela nola lurretik urrun baitago zerua.

¿Nola daiteke hoin mengoa gutiko gauzek eta hoin medea-errechek baduten indarrik aski harritua et balditua idukitzeko izpiritu bat zurea bezain umoa eta ohitua dena traba horiek baino ${ }^{64}$ gaitzagoen hausten eta gainditzen? Segurki hori ez dathor antze eskasetik, bai ordean herabetasunetik eta guti arrazoinatzetik. ¿Nahi duzu ikusi hean egiaz mintzo naizen? Zaude beraz atzarria ene hitzeri, eta ikusiko duzu nola begi sista baten ephean urmariatzen ditudan zure traba guziak eta medeatzen eskas batzu, zeinek diozunaz balditzen eta ${ }^{65}$ loxatzen baitzaituzte hambat non burutik uzten baituzu mundutar argira atheratzea zure don Kijote famatuaren ichtorioa, don Kijote delarik zalduneria ibildaun guziaren argia eta miraila. Eta nik solas hori aditzearekin, ihardesten diot: Hean ¿dugun ikus nola uste duzun chuchendu ni loxatzen nauen makhurra eta garbirat atheratu ene baithan den nahasmendua? -Horren gainean, erraten darot: Lehembiziko gauza trabatzen zaituena, hastapenean ezartzeko eskas ditutzun sonet, epigrama eta laudorio jende handi eta gradotakoek eginik, hori medea daiteke zeronek lan zerbait hartuz hekien egiteko, eta gero bathaya detzazuke eta ezar nahi duzunaren izenean, aitatzat emanez. Indietako Joanes apheza edo Trebisondako emperadorea; badakit berxulari famatuak ${ }^{66}$ zirela; eta hala izan ez balire ere eta gertha badadi ${ }^{67}$ bachiler edo jakinxun direlako zembait egia horren gatik erasiz gibeletik asiki egin darotzuna, ez har bi arditen khechamendurik, zeren gezurra froga baladi ere, ez darotzu nihork hori izkribatu dukeen eskua moztuko. Plama bazterretan aiphatzeko liburuak eta iskribuak zeinetarik athera baituzketzu zure historioan ezarri dituzketzun erran zahar eta berri ez duzu bertzerik egiteko baizik ere

59. Ondoren tatxatuta: nork eskas dituen gauza orotaz

60. Ondoren tatxatuta: heyetan ene $u z$

61. Hitz amaieran tatxatuta: -earekin

62. Ondoren tatxatua: ordutik

63. Ondoren tatxatuta: Bethi iduki izan zaitut

64. Ondoren tatxatuta: handichago diren

65. Ondoren tatxatuta: herabe

66. Ondoren tatxatuta: izan

67. Ondoren tatxatuta: zembait 
ongi heldu den bezala erorraraztea latinezko erran zembait, gogoz dakizkitzunak, edo bederen lan gutiz gostako zaizkitzunak hala-nola libertatez edo gathibutasunez aiphatzea. Non bene $\&$ a .-Eta plama bazterrean ezartzen duzu Horazio edo hori erran izan duena. Herioaren ahalaz mintza bazare berehala atheratzen ditutzu berxu hauk:

\section{Pallida mors $\xi^{a}$.}

Jainkoak exayaren alderat manatzen duen onheskundeaz eta amodioaz balimbada aiphu, berehala sar zaite Iskritura Sainduan, ez baitzaitzu gaitz izanen artha ${ }^{68}$ chume batekin, eta gutienetik errepika zatzu Jainkoaren beraren hitzak: Ego autem $\&^{\mathrm{a}}$. Gogoeta tzarrez mintzo bazare, loth zaite Ebanjelioari: De corde $\&^{\mathrm{a}}$. Adiskideen aldakortasunaz aiphatzen baduzu, huna non Katonek emanen darozkitzun bere berxuak:

\section{Donec $\Psi^{a}$}

Eta latin pozika hoyekin eta holako bertze zembaitekin hartuko zaituzte gutienetik gramatikaritzat, hori ez baita egungo-egunean ez ohore ez probetchetu guti.

Liburuaren ondarrean ezartzeko diren chehetasunez, huna nola egin dezakezun segurtasunekin: mintzatzen bazare zure liburuan digante zembaitez, egizu Goliathez izan dadien aiphua, eta horrekin bakharrik, hurran deusere gosta gabe, baduzu erasia luze baten bidea, ezik erran dezazuke: Golias edo Goliath digantea Filistindar bat zen Dabid artzainak Terebinthako haranean hil zuena habala ukhaldi handi batez errana den bezala Erregeetako Liburuan ${ }^{69}$, egintza hortaz ${ }^{70}$ iskribatua dena aurkhituko duzuen kapituluan.

Bertzalde, kosmografian eta jakitate guzietan zure burua gizon argitutzat erakusteko, haletan egizu non zure liburuan aiphatuko baita Tagoko hibaya, eta horra non duzun berehala chehetasun eder baten bidea. Eta erraten duzu: Tagoko hibaya ${ }^{71}$ horrela deithua izan zen behialako errege español baten izenetik: hulako tokian sortzen da eta Ozeaneko ixasoan galtzen Lisbonako hiri famatuko harrasiak ukitu ondoan eta, diotenez, urhea aurkhitzen da hartako legarretan. Ohoinez mintza, emanen darotzut Kakoren historioa, gogoz baitakit. Emazteki galduez mintzo bazare, horra non den Mondonedo apezpikua; emanen darozkitzu Lamia, Laida $^{72}$ eta Flora eta sinheste handitan ezarriko zaituen chehetasun baten bidea; emazte odolkoyez baduzu aiphu Obidiok emanen darotzu Medea; baldin sorgin eta charmatzaileez bada solasa, Homerok hor du Kalipzo eta Birgiliok Zirze; jeneral handiez mintzo bazare Zezarrek bere burua ematen darotzu bere Comentarioetan eta Plutarkok zuretzat baditu mila Alexan-

68. Ondoren tatxatuta: gaste

69. Ondoren tatxatuta: kapitul

70. Ondoren tatxatuta: dakhart

71. Hitz amaieran tatxatua: $-t$

72. Ondoren tatxatuta: eta 
der. Amoroskerien gainean balimbaduzu hitza, Toscanako mintzayatik izatearekin bi untzaren jakitatea aurkhituko duzu Leon Hebreoren baithan zertaz negurriak kokorreraino bethe. Eta ez baduzu atze herrietara goan nahi ${ }^{73}$, zure etchean hor duzu Fonsekaren ganik Del Amor de Dios, hartan aurkitzen baita zuk eta den izpirituxuenak, holako gauzen gainean gehienik nahi dukeen guzia. Azken buru-buztan ez duzu bertzerik egiteko baizik ere nik erran izen horiek izendatzea zure liburuan edo istorio horiek ukitzea zure istorioan; eta utzazu ene gain ${ }^{74}$ plama bazterretako eta ondarreko chehetasunen artha; nik hitz darotzut betheko ditudala bazterrak eta zikhinduko ditudala liburu ondarrean lau hosto.

Goazen orai bertze liburuetan eta ez zurean ${ }^{75}$ aurkhitzen diren iskribau[en] aiphamenetara. Den errechena da erremedioa, ezik aski dukezu ${ }^{76}$ bilhatzea liburu bat zeintan guziak lerroan ezarriak baitire A-tik Z-raino zeronek diozun bezala. Gero zergada hori bera ezarriko duzu zure liburuan: baldin gezurra garbiki ageri izan badadi ere zeren deus guti probetchu dukezun hortarik, ez da batere achola; eta [o]raino izanen da menturaz zembait gizon ospe laterik uste izateko hetaz orotaz baliatu zarela zure historio laño eta amarrugabean. Eta bertze deuseta $^{77}$ on izan ez baladi ere iskribauen izeneria luze hori baliatuko da gutienetik liburua errespetu puska batean ezartzeko. Eta bertzalde ¿nor hariko da miratzen hean iskribau horieri jarraiki zaren bai ala ez, hortarik deusere behar ez denean ${ }^{78}$ Gehiago dena ${ }^{79}$ ene ustea ustela ez bada, zure liburu horrek ${ }^{80}$ diozun gauza eskas dituelako gauza horien beharrik ez du batere; ezen guzia $\mathrm{da}^{81}$ arbuyatzeko zalduneriako liburuak zeinetaz Aristotelek ez baitzuen deusere nabaritu, Ciceronek deusere jakin Jaun Done Basiliok deusere aiphatu ez eta egiaren zirritutasunak, ez-eta zeruetako izarren gaineko jakitateak deusere ez dute ikustekorik holako asmu sendagailaxu eta moldegaitzetan, ez eta hayentzat mengoarik ez dute ${ }^{82}$ geometriako negurriek ez eta erretorikako ${ }^{83}$ lege eta ihardukitzeek; ez eta ez du nihorri predikurik egiteko batean nahasiz Jainkoari eta gizonari dagozkioten gauzak, hori baita nahastura bat giristinoak onhexi behar ez duena. Ez da imitatu behar iskribatzeko moldean baizik, eta hortan hobekienik imitatua izanen da hobekienik iskribatua. Beraz zalduneriako liburuek munduan eta arronteko jendeetan daukaten ikustate eta sinhestearen ezeztatzeaz ${ }^{84}$ bertzerik ez denaz geroztik zure lanaren chedea, ez duzu zeren eskatzen ibil filosofoeri beren sententziak, Iskritura Sainduari bere konxeiluak, berxularieri beren koplak, erretoreri beren predikuak, ez eta saindueri beren

73. Ondoren tatxatuta: hor duzu

74. Ondoren tatxatuta: et

75. Ondoren tatxatuta: egiten

76. Ondoren ongi irakurtzen ez den zerbait tatxatua.

77. Ondoren tatxatua: ere

78. Ondoren tatxatuta: Eta

79. Ondoren tatxatuta: ongi ikusten baditut gauzak

80. Ondoren tatxatuta: batere ez du beharrik

81. Ondoren tatxatuta: zalduneriako liburuen

82. Ondoren tatxatuta: lur negurtzeko

83. Ondoren tatxatuta: ihardukitze eta

84. Ondoren tatxatuta: denaz geroztik zure lanaren chede 
mirakuluak. Ez duzu bertzerik egiteko baizik ere artha hartzea lanotasunean mintzatuz, zure hitzak izan ditezen ongi hautatuak eta aphainduak, garbiak eta erranak begietarat ederki emanez buruan duzun guzia, batere nahasi eta ixutu gabe. Egizu halaber, gogoz ilhun denari irria ethor dakion zure liburuaren irakurtzean, arrai denari arraizia gehiago, gogo hixekoa ez dadien unha, ernea mirex dadin zure asmu ederrez, gizon seriosak erdeinurik ez dezan athera ${ }^{85}$ zure lanaz eta zuhurra ${ }^{86}$ ez dadin bara laudoriorik eman gabe. Azken buruko, begia idukazu urratzera zaldunerietako liburuen imachina khordokan den hori, gizon hainitzek higuintzen ${ }^{87}$ eta oraino gehiagok laudatzen dutena.

Ichil-ichila egotu nintzen ene adiskidearen solasen entzuten, eta hain ongi ene buruan sarthu ziren haren arrazoinak, non ezta-badaka hasi gabe, ontzat hartu bainituen, eta nahia izan baitut ${ }^{88}$ horietaz beretaz egin ene aintzin-solas hau, zeintan ezagutuko baituzu, irakurle maitea, ene adiskidearen antze chothila, zer zorion izan nuen hain behar-ordu handian kausitzeaz halako konxeilari bat, eta zer gozoa izanen duzun zeronek aurkhitzean bere garbitasun bethean eta itzul-ingururik gabe ${ }^{89}$.

Mantchako don Kijote famatuaren istorioa hain amodio garbiko gizongayrik ez eta zaldun balentik ez baita aspaldi handiko urthetan agertu Montieleko bazterretan, hango jendeen ustearen arabera. Eta ez darotzut espantu sobera egin nahi bihurtzen darotzutan zerbitzuaz zuri ezagutaraztean zaldun bat hain nabaritza eta ospe handitakoa; bainan nahi nuke esker izan diadautazun haren ezkutari Chantcho Pantzarekilako ezagutzaz, ene idurira, haren baithan bilduak baitire eskutari ororen dohain guziak zeinak ez baitire barrayatuak baizik kausitzen zalduneriako liburu alfer eta ezin kondatuzkoetan.

85. Ondoren tatxatuta: eta zuhurrak

86. Hitz amaieran tatxatuta: $-k$

87. Hitz tartean, -tzeren ondoren tatxatuta: -ta-; ondoren tatxatuta: dutena

88. Ondoren tatxatuta: sol

89. Ondoren, hurrengo lerro haseran, tatxatuta: Kijote 


\section{Lehembiziko partea}

Lehembiziko Kapitulua

Nola bizi eta

zer iraulgitarik zen Mantchako don Kijote aitorenseme famatua

Mantchako herri batean, zeinaren izenaz ez baitut orhoitu nahi, bizi zen, ez delarik aspaldi, aitorenseme bat, lantza krakoan daukaten heyetarik eta oraino erredola, ${ }^{90}$ zamalko ihar bat eta charlengoa ihiziko. Eltze bat, maizago bethea behikiz ezen-ez zikhiroki gizenez, arrax gehinenetako haragi hotz pozika zerbait, larumbatetan azienda zango eta muthurkiak, ortziraletan ilharrak, igandetan bertzeen gainera usokume bat, horiek aski ziren iresteko haren onthasunetako bilkinen hirur laurdenak. Chahutzen zuen ondarra igande ${ }^{91}$ bestetako eginez aldagarri bat oihal finez ${ }^{92}$, galtza pare bat belurez eta zapata mehaxak oihal beretil, eta astelegunetan bere buruari ohore ematen zion tela politenezko chamar batekin. Etchean bazuen gobernant bat berrogoi urthez goitiko, neskatcha gazte bat bere iloba hogoyetara hurbiltzen zena, eta mutil bat kampo-barnetako, zaldi zelatzen hain ongi hari zena nola egur chehatzen. Berrogoi eta hamar urtheren inguruxuan zabilan gure aitorensemearen adina. Gorphutzez hazkar zen, haragiz ihar, mokoz mehar, goizetan goichtiar handi eta ihicerat emana. Batzuk diote Kijada zuela izengoitia, biltzuk Kesada (ezik horren gainean makhur zerbait bada etche hartaz mintzatu diren iskribauen artean) nahiz ara gehiago duen uste izateko Kijana deitzen zela. Bainan horrek mengoa guti gure istorioarentzat, gauzen erratean ez bada ile batez egiatik urruntzen.

Bada, jakin behar da gure aitorensemea alfer egoten zen arteetan (eta hori zen urthe gehienxuan) zalduneriako liburu irakurtzen hari zela hambat amodio eta gogorekin, non ${ }^{93}$ ihizitan ibiltzea eta bere onthasunen artha hurrantto ahantzi baitzituen. Hain urrun hedatu ziren haren kuriostasuna eta erhokeria, non saldu baitzituen bere landetarik asko golde lur, heyen sariaz erosteko zalduneriako liburu irakurtzekoak, eta hola etchera bildu zituen atzeman ahal guziak. Bainan orotarik etzitzayon batere hain ederrik nola Feliziano Silba famatuak egin izan dituenak; ezik haren hizkuntzaren garbitasuna eta solas karabilkatuak iduritzen zaizkon perlak; eta gehienik ethortzen zenean irakurtzera ${ }^{94}$ amodiozko eta desafiozko gutun hek, zeinetan iskribatua aurkitzen baita behin baino gehiagotan: Ene arrazoinari egiten diozun desarrazoinezko arrazoina, hambateraino iraungitzen du ene arrazoina non arrazoinekin arranguratzen bainaiz zure edertasunaz. Eta orobat irakurtzen zuenean: Zeru gorak, zeinek zure jainkotasuna

90. Ondoren tatxatuta: zaldi

91. Hitz amaieran tatxatuta: -tako

92. Hitz honetatik hasita tatxatuta: -koa belurezko

93. Ondoren tatxatuta: hurran

94. Hitz haseran tatxatuta: $h$ - 
jainkozki izarren laguntzarekin hazkartzen baitzaituzte eta merezdun egiten zure handitasunak merezi dituen merezimenduez.

Holako solasekin, aitorenseme gaizoak galtzen zuen kaskoa. Gauak [e]maten zituen horien aditzeko eta erroraino ezagutu beharrez zer erran nahi zuten, noizere Aristotelek berak ezin eginen baitzuen, baldin hortako bereko berariaz itzuli izan balitz mundura. Etzituen hain lakhet don Belianisek ematen eta hartzen zituen ukhaldiak, zeren bururatzen baitzitzayon, barberik handienak ethorririk ere heyen sendatzera, etzirela gutigo horren gatik gorphutza eta begithartea geldituko zirri-marra eta zarrastakoz betheak.

Guziagatik, laudatzen zuen liburuaren egilea akhabatu zuen moldeaz, ezin akhabatuzko gerthakari haren agintzarekin. Eta askotan gogora ethorri zitzayon, hegaxa harturik behar zuela akhabatu, hitzez hitz liburuan errana den bezala. Ez dudarik batere egin ${ }^{95}$ izan zukela eta ohorezki ere atheratuko zela, baldin bertze gogoeta handiago batzuk ez baliote bethi burua hantua iduki.

Askotan ezta-bada haritua zen bere herriko erretorarekin (gizon jakina eta Siguenzan gradoak izana) hean ${ }^{96}$ zaldun hobea zein izan othe zen, Palmerin Angeletierrakoa ala Amadis Gaulakoa. Berriz, Nikolas, herriko bizarregileak erraten zuen batere etzela izan Febeko zaldunari hurbildu zenik, eta bat balimbazen haren khideko eman zitakeenik, hura zela don Galaor, Amadis Gaulakoaren anaya, zeren on izan baitzen edozein gauzetako, ez zaldun milikatu bat, ez nigarti bat bere anaya bezala, eta bihotz erakusteko orduetan haren gibeletik etzagoena.

Azkenekoz, gure aitorensemea hambateraino thematu zen bere liburuetan non gauak irakurtzen ematen baitzituen argiz argi, eta egunak iguzkiz iguzki; eta hola, lo guti eginez eta hainitz irakurtuz, burmuinak idortu zitzaizkon haletan non ethorri baitzen zentzuaren galtzera. Haren izpiritua bethe zen liburuetan irakurtu zituen horiez oroz, charma, aharra, desafio, gudu, ukhaldi, amodiozko solas, amoroskeria, phena eta ezin ditazkeen moldegaizkeria guzietaz. Eta horiek buruan hain ongi sarthu zitzaizkon, non irakurtu zituen asmu eta amexeria hori oro egia garbiak baitziren harentzat, eta munduan ez baitzaukan bazela istorio segurragorik. Erraten zuen Rui Diaz Zidoa zaldun on eta ona izan zela; bainan etzela hurbiltzen Ezpata-Biziko zaldunari, zeinak errebesiara ezpata ukhaldi bakharraz erditik moztu baitzituen bi digante gaitz eta ikharagarri. Eta gehiago zaukan oraino Kampioko Bernat, zen Arrontzeballen hil izan zuen Arrolan charmatua, eginez Herkulesek bezala, hunek besoen artean lehertu zuenean Anteon, Lurraren semea. Ongi hainitz erraten zuen Morgano diganteaz, zeren nahiz izan zadin bigante iraulgi hartarik zeinaren ume guziak baitire ozarrak eta nabarmenak, hura bakharrik baitzen aho gozokoa eta onxa ikasia. Bainan guziak baino maiteago zuen Errenaut Montobanekoa, bereziki ikusten zuenean bere gaztelutik atheratzen, bidean atzeman guzien arrobatzen, et allenden ebaxi zuenean Mahometen idola, zeina guzia urhezkoa baitzen histo-

95. Hitz amaieran tatxatuta: -en

96. Ondoren tatxatuta: Palmerin Angeletierrakoa ala Amadis Gaulakoa izan othe zen 
rioak dionaz. Berriz, Ganalon traidoreari ehun ostiko gibelean emateagatik, salduko zuen bere etcheko gobernanta eta iloba gainetik.

Azkenekoz, burutik alde bat arindurik, erori zen egundaino munduan erho batek ${ }^{97}$ egin dukeen asmu sorjesenera. Iduritu zayon gisa zela eta premia ere, ala bere ohorearen berhatzeko, ala erresumari zerbitzu egiteko, egin zadin saldun ibildaun, eta goan zadin herriz herri mundu guzia gaindi, bere harma eta zaldiarekin, gerthakari ${ }^{98}$ ketara, eginez zaldun ibildaunek (liburuek erran ziotenaren arabera) egiten ohi dituzten balentriak, makhur guziak chuchenduz, bere burua asturu gaitz eta lanjer guzietan sarthuz, biltzeagatik hek gaindituz bethiko omen eta ospea. Zoro gaizoak jadanik amesten zuen bere burua bere balentrien gabik khoroatua bederen Trebisondako emperadore khoroaz: eta holako asmu gozoekin, hetan aurkhitzen zuen gostu gaitzak harroturik, herresakan abiatu zen ${ }^{99}$ bere lehiaren obratzera. Egin zuen lehembiziko gauza izan zen garbitzea harma batzu, haren arbasoetarik heldu zirenak, aspaldiko mendetan zokho batean ahantziak zaudenak mutziturik eta herdoilez betherik. Argitu zituen eta ahal bezain ongi chuchendu, bainan ohartu zen eskas handi bat bazutela; kask[a] osoa izan behar bidean bere zathi guziekin, erdi murriztua zen. Orduan bere antze guzia gauzaren chuchentzen ezarririk, kartoin puska batez egin zuen eskas zena, eta ${ }^{100}$ hura kaska murritzari berhatu ${ }^{101}$ ondoan, kaskak iduri zuen ${ }^{102}$ osoa zela. Egia da, ikusi nahiz hean hazkarra zen, eta jasan ahal othe zezakeen sabre ukhaldi on bat, atheratu zuela bere ezpata, eman ziozkala bi ukhaldi eta urratu lehembizikoaz ez deus batean aste batetako lana. Puskatzeko errechtasun horrek etzion boztu gogoa; eta holako lanjer baten kontra seguratzea gatik, hasi zen berriz bere kaska tzarraren moldatzen. Barnetik ezarri ziozkan burdin usteitto batzu, haletan non kontent gelditu baitzen haren hazkartasunaz, eta berriz frogatzea bilhatu gabe, ontzat iduki zuen eta kaska oso den finenarentzat.

Gero, goan zen berehala bere chamalkoaren ikustera, eta nahiz bazuen sosak ardit baino zibela gehiago eta Gonelaren zaldiak baino errezelu gehiago, zeina ez baitzen hezur eta larru baizik, uste izan zuen haren pare etzirela ez Alexanderren Buzefalo ez Zidoaren Bibieka. Lau egunez asmatzen haritu zen hean zer izen emanen othe zion (ezik bere buruari erraten zion) hain zaldun famatuaren zaldia, eta berenez hain zaldi ona, geldi zadin izen ezagutu bat gabe, eta holetan hari zen chuchendu nahiz izen bat zeinak erranen baitzuen zer izan zen zaldi hura zalduneria ibildaunean sarthu aintzinean eta zer zen berriz orduan. Eta oraino, arrazoin soberatua zen nausia ofizioz gambiatzen zen ordutik, zaldiari ere alda ziozon izena eta bat eman famatua eta harrabox handitakoa eta hartzen zuen ordena et ofizio berriari zagokiona. Eta hola zembat eta zembat izen asmatu, hartu, utzi, luzatu, laburtu, egin eta desegin ondoan,

97. Ondoren tatxatuta: izan

98. Ondoren tatxatuta: keta

99. Ondoren tatxatuta: lehi

100. Ondoren tatxatuta: kaska

101. Hitz amaieran tatxatuta: $-z$

102. Ondoren tatxatuta: kaska 
azkenekoz ${ }^{103}$ bere zaldia deithu zuen Errozinante, izen, haren iduriko, ederra, harrabosduna, markatzen zuena zer zen lehen eta orai, munduko zamalkoetarik lehen-lehena.

Bere zamaria eman ondoan izen bat hain gostukoa, bere buruari ere bertze bat nahi izan zion berezi; eta asmu hortan zortzi egunez gogoetaka egon ondoan, azkenean hautatu zuen don Kijote deitzea. Hortarik atheratu du (lehen erran dena) istorio guziz egiazko hunen iskribataileek, Kijada deitzen zela dudagabe eta ez Kesaja, zembait erran nahi izan duten bezala. Orduan orhoiturik Amadis balentari etzitzayola aski izan bere buruari ematea izen bat murritz-murritza, eta luzatu zuela bere sort-herriaren izenaz hura fama handitan ezartzeagatik, eta bere burua deithu zuela Amadis Gaulakoa, hala nahi izan zuen harek ere, zaldun on arara, bere izena herriaren izenaz luzatu eta deithu don Kijote Mantchakoa, harekin iduritzen baitzitzayon ezagutarazten zituela ahal den hobekienik bere iraulgia eta herria eta ohoratzen zuela bere herria hartarik hartuz bere izen goitia.

Beraz harmak garbitu ondoan, kaska murritzetik kaska osoa egin, chamalkoari izen bat eman eta berak ere bertze bat hartu, buruari eman zion etzuela bertzerik deusere eskaz baizik ere bilhatzea andre bat hartas amoros erortzeko; ezen, haren idurira, zaldun ibildaun bat emaztegayrik gabe, arbola hosto et fruitu gabe bat da, gorphutz arima gabe bat. Eta hau erraten zion bere buruari: Ene bekhatuen gatik edo zori onak emanik hor gabi digante zembait buruz buru egiten badut zaldun ibildauneri gerthatzen ohi zayoten bezala, eta loth-aldi batean lurrerat ematen badut, edo ezpataz bi pusketan ezartzen edo azken buru-buztan garhaitzen eta errendarazten badut iez othe lizate on izatea nori hura bidal present gisa, sar dadin eta belhaunen gainerat eror ene ${ }^{104}$ charmagarriaren aintzinean, diolarik mintzo humil eta hezi batekin: Ni naiz Karakuliambro digantea, Malindraniako irlako errege, zeina ${ }^{105}$ buruz-burukako gudutan garhaitu izan baitu behinere behar bezala ezin laudatuko den zaldun don Kijote Mantchakoak; haren manuz nathor ${ }^{106}$ berorren eskerraren aintzinera, berorren handitasunak nitaz egin dezan berak gogoan duen guzia. Oi nola boztu zen gure zaldun gaizoa solas eder hori atheratu zuenean eta oraino hobeki kausitu zuenean nor deith bere andre! Hura izan zen, uste dutenaz neskatcha laborari bat, itchura ederrekoa, hauzo herri batean egoten zena, zeintaz demboran agrados gerthatu baitzen, nahiz ${ }^{107}$ aditzen dena neskatchak etzuela behinere jakin eta etzela ere ohartu. Deitzen Aldonza Lorenzo eta hura iduritu zayon gisakoa hari emateko bere gogoko andrearen izena. Eta harentzat bilhatzean izen bat berearen ganik guti urruntzen zena eta andre handi edo printzeza batenera hurbiltzen eta enkaratzen zena, asmatu zuen deitzea Dulzinea Tobosokoa zeren sortzez Tobosokoa baitzen. Izen hori berriz, iduritzen zitzayon gozoa; ez arronta, bainan senxutakoa, hala nola ordu arteo beretzat eta bere gauzentzat hautatu zituen guziak.

103. Ondoren tatxatuta: deithuz

104. Ondoren tatxatuta: andre behar

105. Ondoren tatxatuta: $g a$

106. Ondoren tatxatuta: zure

107. Ondoren ongi irakurtzen ez den zerbait tatxatua. 
II $^{\text {rren }}$ Kapitulua

Don Kijote handiaren lehembiziko ilkhialdia

Beraz gauza guziak hola chuchendu zituenean, bere asmuaren obratzea etzuen nahi izan gehiago luzatu. Hartara gehienik herxatua zen gogoeta batez ${ }^{108}$, iduritzen baizitzayon geroagorat egonez bidegabe ekhartzen ziola munduari, bere ustez ${ }^{109}$ desegiteko zituen gaizki guzien, chuchentcheto zituen makhurren, antolatzeko zituen aragabekerien, medeatzeko zituen abusuen eta zor pagarazteko zituen guzien gatik. Holetan nohorri salhatu gabe burutan zuena, eta nihor ohartu gabe, goiz batez, argia baino lehen (hura zen ustaileko egun beroenetarik bat) soinean ezarri zituen bere harmak, igan zen Errozinanten gainera, buruan ezarri zuen bere kaska gaizki moldatua, musu eman zion bere erredolari, hartu zuen bere lantza, eta korral bateko bazterreko athetik ilkhi zen ${ }^{110}$ espazioa zelhayera, ongi bozik ikusteaz zein errechki abiatu zuen bere lehia ${ }^{111}$ onaren hastapena. Bainan bere burua kampoan ikusi zuen orduko, gogoeta bat jausi zitzayon ikharagarria eta hambatekoa non ezdeus guti batean utziko baitzuen abiatu urhaxa: bururat ethorri zitzayon etzela zalduntzat harmatua, eta zalduneriako legearen arabera, etzuela zuzenik eta etzuela behar zaldun baten kontra harmetarat atheratu, eta hala izan balitz ere ${ }^{112}$, harma churitan ibili behar zela ${ }^{113}$, zaldun berri bezala, erredolan seinalerik gabe hura bere balentriez irabazi arteo. Gogoeta horiek khordokarazi zuen bere chedean. Bainan harren buru harrokeria arrazoin guzieri nausiturik, gogoan hartu zuen behar zuela bere burua zalduntzat harmarazi bidean atzemanen zuen lehembiziko gizonaz ${ }^{114}$, bertze askok egin izan $^{115}$ zuten $^{116}$ bezala halakatu zuten liburuek ziotenaren arabera. Harma churiez bezembatean, bere baithan egin zuen lehembiziko artean argituko zituela bere harmak hain ongi non eginen baitzituen elhurra bera baino churiago. Holetan jabaldu zuen gogoa eta bideari jo zion aintzina zaldiak nahi zuen alderat ${ }^{117}$, bazaukan ezen hortan zagola gerthakarietako indarra. Beraz gure zaldun berria bidean zihoalarik solasean hari zen bere buruarekin eta erraten zuen: ¿Nork duda, ethorkizuneko demboretan hedatuko denean ene balentrien istorioa ${ }^{118}$, hek iskribatuko dituen iskribau zuhurra ${ }^{119}$ ethorriko denean ene lehembiziko ilkhialdi goichtiar hau, hulache baizik ez dela mintzatuko: «Apolon musugorriak lurraren hedadura zabalera

108. Ondoren tatxatuta: uste baitzuen

109. Ondoren tatxatuta: chuchentzeko zituen makhur guzien gatik

110. Ondoren tatxatuta: kampoetara

111. Hitz honetatik hasita $-n$ tatxatuta

112. Ondoren tatxatuta: seinale gabe

113. Ondoren tatxatuta: erredolan seinale

114. Ondoren tatxatuta: hala-nola

115. Ondoren tatxatuta: zuten

116. Hitz hasieran tatxatuta: bait-

117. Ondoren tatxatuta: gert

118. Ondoren tatxatuta: hunela baizik

119. Ondoren tatxatuta: mintzatuko dela hulache:« 
barrayatu orduko bere ilaya ederreko chorroin urztatuak, mila koloretako chorittoek beren mihiko chirribikarekin, musika ezti eta gocho batez ${ }^{120}$ agur egin zioten orduko argizkorri arrosa iduriari, zeinak utzirik bere senhar bekhaizkorraren etrauntza guria, bere burua gizoneri erakusten baitiote Mantchako ortzi gaineko athe eta galerietarik, Mantchako don Kijote zaldun famatua ${ }^{121}$, utzirik bere lumatcha nagiak, igan zela bere zaldi famatu Errozinanteren gainera eta bere bidea hartu zuela Montielgo zelhai aspalditik deithatuak gaindi (eta egia da han gaindi zihoala) eta aintzinat ${ }^{122}$ erasiz, erraten zuen: «Urthe dohaxuak, mende dohaxua zeintan argitara ilkhiko baitire ene balentria famatuak, merezi duketenak bronzean zizelatuak izatea, marmolan harginduak eta paneletan pintatuak ethorkizuneko mendeen orhoitzapenarentzat! Oi zu, charmari jakinxuna, nor nahi izan zadin, zeina baitzaitake dohatua istorio harrigarri hunen iskribatzeko, ez ahantz othoi ene Errozinante ona, ene bidaya eta urhax guzietako laguna!» Gero lotzen zen berriz ${ }^{123}$, egiazki amorostua balitz bezala: «Oi printzeza Dulzinea, bihotz gathibu huntako andrea! irain handi egin darotadazu ni despegituz eta zure ganik iraiziz zorroztasun guziarekin, manatu nauzunean ez nadin ager zure edertasunaren aintzinera. Onhex zazu othoi, andrea, zure manupeko ${ }^{124}$ bihotz hunen ${ }^{125}$ zure gatik hambat oinhaze jasaiten duen bihotz hunen orhoitzapena.» Bazohan zorokeria hoyen gainera bertze asko metatuz, guziak bere liburuek irakaxi ziozkatenen arakoak, ahalaz liburu hetako hizkuntzetarat hurbilduz. Eta hola-hola aintzinat zihoan hain emeki, eta iguzkia igaiten zen hain gora eta hain zen erregarria, non aski baitzitaken gure zaldunari burmuinen urtharazteko baldin ondar zembait izan balu.

Egun hura gehiena bidean eman zuen aiphatzea balio duen gauzarik gerthatu gabe; eta horrek desesparatzen zuen, zeren bere-berehala nahi baitzukeen norbait atzeman harekin frogatzeko bere beso hazkarraren balentasuna. Iskribauak badira diotenak ${ }^{126}$ Lapitzeko lephoko gerthakaria izan zuela lehenbizik[oa] ${ }^{127}$ bertze batzuk diote haizezko iharetakoa zela lehena. Bainan nik athera dutan egia eta Mantchako urtharietan iskribatua aurkhitu dutana hau da, egun hura guzia bidean eman zuela, eta ilhuntzean bera eta bere zaldia phorrokatuak eta gosez hilak aurkhitu zirela; eta alde orotara behatuz hean ageri othe zen zembait jauregi edo artzain etchola ${ }^{128}$ han gelditzeko eta bere behar-ordu handian laguntza zerbaiten kausitzeko, bere bidetik hurbil ikusi zuen menta bat. Hura izan zen harentzat zeruko atheetara edo salbamenduko portura daraman izarra iduri. Zalhutu zuen urhaxa eta heldu izan zen ilhuna erortzen zen orduan. Suerteak emanik athean baziren bi neskatcha gazte, lilitchoak deitzen

120. Ondoren tatxatuta: argizkorri arrosa iduriari

121. Hitz amaieran tatxatuta: $-k$

122. Ondoren tatxatuta: mintzatuz

123. Ondoren tatxatuta: norbaitez

124. Ondoren tatxatuta: don

125. Ondoren tatxatuta: orhoitzapena

126. Ondoren tatxatuta: lehembizi

127. Eskuizkribuan lehenbizik- da ongi irakur daitekeena. Gainontzekoa, zerbait idatzi ondoren gainetik gaindatzia dagoenez, zail egiten da bertan jartzen duenaz jabetzea. Suposa daiteke testuinguruagatik lehenbizikoa behar duela.

128. Ondoren tatxatuta: zeintan 
dituzten hetarik, zeinak Sebillara ${ }^{129}$ mandozain batzuekin zihoazilarik menta hartan gerthatu baitziren gauaren ematera. Eta nola gure gerthakari zaleari, bururerat edo begietarat ethortzen zitzaizkon gauza guziak iduritzen baizitzaizkon egiten eta iragaiten zirela hala-nola liburuetan irakurtu zituenak, menta ikusi zuen orduko iduritu zitzayon gaztelu bat bere lau dorreekin, zilhar argituzko harroin buruekin, ahantzi gabe airezko zubia, inguruan errekekin eta holako jauregiek liburuetan dituzten bertze edergailuekin. Hurbildu zenean mentara (zeina jauregitzat baitzaukan) baratu zuen zaldia, igurikiz ñaño zembait ager zadin harrasi zirrituetara turutarekin seinalatzeko zaldun bat gaztelura heltzera zihoala. Bainan ikusirik luzatzen zutela eta Errozinanek presa zuela zalditegia, goan zen mentako athera eta ikusi zituen han geldituak ziren bi neska tzarrak. Iduritu zitzaizkon bi neskatcha gazte eder edo bi andre grazios jauregiko athirian beren axeginera gozo hartzen zaudenak.

Ordu berean gerthatu zen zizkir batzuetan urdezain batek biltzen zituelarik bere urdeak (ez da zeren barkhatu, hori beren izena dute) jo zuela adarra zeren seinale hartara biltzen baitire azienda hek; eta berehala don Kijotek uste izan zuen, bere nahiaren arabera, ñaño zembait [ek] ${ }^{130}$ ematen zuela haren arribadako albichtea. Eta hola bozkario handitan hurbildu zen mentara eta bi neskatchen gana. Hauek ikusi zutenean gizon tresna hura harmetan lantza erredolekin, izialduraz betherik menta barnerat ihes egiten zuten. Bainan don Kijotek ezaguturik haren beldurrak eragiten ziotela ihes, goititu zen bere kartoinezko ikustegia, eta agertzen zuelarik bere moko mehar herrauxez estalia mintzo ezti bat eginez erran zioten amulxuki: «Berorien eskerrek ez bezate ihes egin, ez eta ${ }^{131}$ zerbait hobenen beldurrik ez izan; ezik zalduneriako ordenan (eta hura da ene ofizioa) egimbide bat da ${ }^{132}$ gaizkirik ez egitea nihori, ${ }^{133}$ zembatez ere gutiago ${ }^{134}$ neskatcha zuek bezain grado handiko direneri, zuen begitharteek erakusten duten bezala.» Bi neskek beha ${ }^{135}$ zagotzion eta ${ }^{136}$ eta begiz bilhatzen zuten ikustegi tzarrak itzaltzen zioten mokoa. Bainan aditu zutenean andre deitzen zituela (gauza heyen ofiziotik hain urrun zagona) ezin atchiki zuten irria, eta halako moldez non don Kijotek damu harturik, erran baitzioten: Andre ederretan eder da kortesia eta ergelkeria bat da gauza ez deusetik heldu den irria ez darotzuet hori damu egitekotan erraten ez eta omore tcharretan zuen ezartzeko, nerorek bertze gogorik ez dudanean zuen zerbitzatz[ea] ${ }^{137}$ baizik ${ }^{138}$. Etziren holako solasak bi andretchoen buruko; horiek eta gure zaldunaren itchura gaitzak irri gehiago

129. Ondoren tatxatuta: zihoazelarik menta hartan gerthatu baitziren

130. Eskuizkribuan lerro amaieran dagoen hitz honetan zembait- irakur daiteke. Testuinguruari esker suposa dezakegu ergatiboaren - ek falta dela.

131. Ondoren tatxatuta: beldurrik izan

132. Ondoren tatxatuta: nihor

133. Ondoren tatxatuta: eta guziz

134. Ondoren tatxatuta: zuek bezain grado handiko

135. Hitz honetatik hasita tatxatuta: -tzen zuten

136. Ondoren tatxatuta: heyen begiz bilha zabiltzan

137. Eskuizkribuan lerro amaieran dagoen hitz honetan zerbitzatz-irakur daiteke, nahiz eta atzetik zerbait duela antzeman. Zerbitzatzea aditz izena dela esan daiteke hitz horren atzean dagoena.

138. Ondoren tatxatuta: Andretchoak 
eragiten zioten oraino eta samurrarazten zuten don Kijote; eta gauzak gaizkirat itzuliko ziren, baldin ordu hartan ilkhi ez balitz mentazaina, gizon lodi bere zorro handia ${ }^{139}$ gatik bakearen adiskide $^{140}$ zena. Hunek ikusi zuenean begitharte bitchi hura, hain moldegaizki harmatua bere brida tchar, lantza, erredola eta gerruntzearekin, deus guti batek egin zuen ez baitzen neskekin abiatu bere omore ederraren erakusten. Bainan harma eta tresna heyen ororen beldurrez, nahi izan zuen polliki mintzatu, eta huna zer erran zuen: «Zaldun jauna, zure eskerra ostatu keta balinbadabila, ohea salbo (ezen bakhar bat ere ez da menta huntan) gainerako guzia nasaiki kausituko du hemen». Don Kijotek ikustearekin gazteluko kapitainaren humiltasuna (gaztelutzat eta ${ }^{141}$ kapitaintzat zaduzkitzan menta eta mentazaina) ihardexi zuen: «Gaztelu-nausia, enetzat edozein gauza aski da; ezen harmak dire ene edergailu ${ }^{142}$, guduak dire ene pausu $\&^{a}{ } \gg$. Ostalerak uste izan zuen don Kijotek gaztelu nausi deithu zuela ${ }^{143}$ hartzen zuela gazteluaren ihes zabilan zembaitentzat, nahiz Andaluziarra izan zadin eta Sanlukarra aldekoa, ez Kako baino gutiago ohoina, ez ichtudiante bat edo lekhayo bat baino gutiago trufaria. Eta hula ihardexi zion: Khondu hortan, zure eskerrak ditu.

Harri kotorrak ohetzat

Bethi beilatzea ere lotzat

Hola denaz geroztik, jaux zaitezke aberetik, segur-segura etchola huntan atzemanen duzula okasionea eta okasioneak ere emateko ez gau bat bainan urthe guzia lorik egin gabe».

Hitz horren gainean, goan zen estriberaren atchikitzera don Kijote, zeinak lan eta neke izan baitzuen jausteko, hala-nola egun guzian burura hauxi gabe zen gizon batek. Ostalerari erran zion berehala artharik handiena izan zezala zaldi hartaz zeren hura baitzen belharra jaten duen munduko abererik hoberena. Mentazainak zaldiari begiratu zion eta etzitzayon iduritu don Kijotek zion bezain ona zela ez-eta erdiaz ere. Arrimatu zuen bada zalditegian eta itzuli zen ikustera hean zer nahi zukeen gure zaldunak. Ordukoz, neskatchak hunekin bakeak eginik, hari zitzaizkon ${ }^{144}$ soinetik harmen khentzen. Khenduak zituzten bai aintzin-gibeletako gerruntzeak, bainan egundaino ezin deslotu zioten lephokoa ez eta lachatu bere kaska moldegabea zeina chingola ferdez ${ }^{145}$ tinkatua baitzen. Moztu behar ziren korapiloak ezin barraya ${ }^{146}$ zitazkelakoz; harek ordean niholaz ere etzuen nahi izan onhexi. Haletan gau ${ }^{147}$ guzian gelditu zen kaska buruan, hala egiten baitzun ikus ditakeen begitharterik pollitena eta ezin bertzea. Harmak khentzen ziozkatenean, nola buruari eman baitzion lan hortan hari ziren neska gal-

139. Hitz amaieran ongi ikusten ez den zerbait tatxatua.

140. Ondoren tatxatuta: egit

141. Ondoren tatxatuta: zaduzkat

142. Hitz amaieran tatxatuta: $-a k$

143. Ondoren tatxatuta: iduritu zitzayolakoz

144. Ondoren tatxatuta: harmen

145. Ondoren ongi irakurtzen ez den zerbait ezabatua

146. Ondoren tatxatuta: zitelakoz

147. Ondoren tatxatuta: hura 
duak gaztelu hartako andre handi zembait zirela, erran zioten esker ederrenarekin:

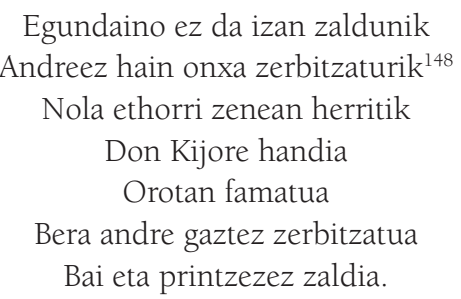

edo Errozinante, ezen ene andrettoak, hori da ene zaldiaren izena eta ${ }^{149}$ nerea don Kijote Mantchakoa ${ }^{150}$ : ez narotzuen ${ }^{151}$ agertu nahi, ${ }^{152}$ zuen zerbitzuko eta onetan egin balentriek ezagutaraz nintzaten baino lehen, Lantzalote kantore zahar hori oraiko kasuari arrimatu beharrak egin du ordua ethorri gade jakiten duzuela ene izena; bainan ethorriko da orena zeintan zuen eskerrak manatuko baitu eta nik obedituko eta ene beso balentaren indarrak erakuxiko baitu zembatekoa den nik zuen zerbitzeko dutan lehia gaitza». Neska hek ez baitziren holako solas ederretara jarriak, etzuten hitz bat atheratzen; bakharrik galdatu zioten hean zerbait etzuenez jan nahi. Don Kijotek ihardiexi zuen: «Jan nezake edozein gauza, ezen ene gogoko hainitz onxa ethorria lizate».

Zori tcharrak emanik, egun hura gerthatzen ortzirale bat, eta menta guzian etzen arrainki puska batzuez bertzerik; arrain hura ${ }^{153}$ marluza deitzen baita Castillan, bakallaua Andaluzian eta ${ }^{154}$ amarraintchoa bertze toki batzutan. Erran zioten hean ez ${ }^{155}$ zuen haren eskerrak $^{156}$ amarraintchorik janen othe zuen, etzela bertze arrainik hari aintzinerat emateko. Don Kijotek ihardexi zuen: «Amarraintchoa balimbadire hainitz, baliatuko dire amarrain batentzat, iezen zer dohakit izan detzadan hogoi sos eginak edo pezeta batean hogoi sos? Bertzalde, baditake amarraintcho horietaz gertha dadin hala nola aratchekiaz zeina samurrago baita ${ }^{157}$ behia baino, pittika akherra baino. Bainan dena dela, laster ethor bedi, zeren lana eta harmen dorphea ez ditazke jasan hertzeak huxik badaude». Mentako athean ezarri zioten mahaina freskuraren gatik, eta ostalerak ekharri zuen bakallau puska bat urean ez hambat gezatua eta oraino gaizkiago egosia eta ogi bat hain beltza eta zikhina nola zaldun ${ }^{158}$ beraren harmak.

148. Ondoren datozen bi bertsolerro tatxatuta: Nola don Kijote handia / orotan famatua

149. Ondoren tatxatuta: don

150- Ondoren tatxatuta: nahiz ba

151. Ondoren tatxatuta: ene burua

152. Ondoren tatxatuta: ene balentria

153. Ondoren tatxatuta: abendejo

154. Ondoren tatxatuta: trutchuela

155. Ondoren tatxatuta: othe

156. Ondoren tatxatuta: bakallauak

157. Ondoren tatxatuta: ezenaz

158. Hitz amaieran tatxatuta: -aren 
Bainan irriz leher-egiteko zen hura jaten ikustea; ezen buruan baitzadukan kaska eta ikustegia goratua, etzezakeen deusere ahorat hel bere eskuz, nihork ez bazion ahorat ematen, eta hola neska hetarik baten hartu zuen kargu hori. Bainan ezin eman zezoketen edatera, eta ezina geldituko zen hori, baldin mentazainak zilhatu ez balu kanabera bat, eta muthur bat ahoan ezarririk, bertzetik ichurtzen zion arnoa. Zaldun gaizoak horiek oro khechatu gabe hartzen zituen; ez hausteagatik bere kaskako lokharriak. Hortan zirelarik suerteak mentara ekharri zuen cherri chikhiratzaile bat, eta harat heltzearekin, lau edo bortz aldiz jo zuen bere chirula. Hori aski izan zen don Kijoteri amexa zin-zinez buruan sartzeko zembait gastelu famatutan zela ${ }^{159}$, musikarekin ematen ziotela jatera, ${ }^{160}$ amarraintchoa amarrain zela; ${ }^{161}$ ogi beltza churi zela, neska tzarrak andre, eta mentazaina gazteluko jaun; eta ${ }^{162}$ aria hortaz, ongi emplegatutzat zaduztan hartua zuen chedea eta bere ilkhialdia. ${ }^{163}$ Arrangura gehiago zuen bere burua ez ikusteaz zalduntzat harmatua, zeren iduri baizitzayon etzaitekeela zuzen bidez gerthakari zembaitetan sar zalduneriako ordenan onhexia izan gabe.

$$
\text { III }{ }^{\text {en }} \text { Kapitulua }
$$

Zeintan erraten baita zer molde pollitetan zaldun harmatua izan zen don Kijote

Gogoeta horrek khechaturik, zalhuki igorri zuen mentako afari chuhurra; eta akhabatu zuenean, deithu zuen mentazaina eta harekin bere burua heyan herxi zuen. Orduan haren aintzinean belhauriko jarririk, erran zion: «Naizen tokitik ez naiz ${ }^{164}$ sekulan chutituko, zaldun balenta, zure kortesiak onhex diazadan arteo galdegin nahi darotzudan dohain bat, hura izanen baita zure bethiko ohoretan eta gizon kasta guziaren onetan». Mentazainak bere oinetan ikusi zuenean don Kijote ${ }^{165}$ eta holako solasak aditzaz, balditua zagon hari begira; etzakien ez zer egin ez zer erran eta baitezpada chutiarazi nahi zuen. Bainan etzuen ahal hori izan agindu arteo onhesten ziola galdatu dohaina. Don Kijotek ihardexi zion: «Ene jauna, ez nuen gutigo igurikitzen zure ${ }^{166}$ bihotzeko aberastasun handitik, eta holetan erraten darotzut nik zuri galdatu eta zure bizartasunak niri onhexi dohaina dela zuk bihar goizean zalduntzat harma nezazun. Gaur zure jauregiko kaperan eginen dut harmetako beila, eta bihar goizean erran dutan bezala, betheko da hain lehia handiz lehiatzen dutan gauza, behar den bezala goan ahal nadien munduko lau basterrak gaindi gerthakari ketara beharretan diren guzien onetan zalduneriako eta ni naizen bezalako zaldun ibildaunen egimbideak manatzen duenaren arabera, holako balentrietara ene bihotzak ekhartzen nauen bezala».

Aichtian erran dena, mentazaina maltzurskoa baitzen eta orduko nabarmendua haren

159. Ondoren tatxatuta: eta

160. Ondoren tatxatuta: eta

161. Ondoren tatxatuta: neska tzarrak

162. Ondoren tatxatuta: holetan

163. Ondoren tatxatuta: Gehiago

164. Ondoren tatxatuta: sekul

165. Ondoren tatxatuta: balditua zagon hari begira

166. Ondoren tatxatuta: [ _ ] handitik 
gizonak burutik bazuela eskas zerbait, sinheste osoa hartu zuen aditu ziozkanean holako solasak; eta gau hartan irriz asetzea gatik, gogoan hartu zuen haren buruzkinkeriari bide eman behar ziola. Erran zion beraz asmo onekoa zela haren lehia, halako chedea ethorkiz eta berenez dutela hain sortze handitako zaldunek nola baitzen ezagun hura eta nola erakusten baitzuen ongi haren patchada ederrak; bera ere, bere gaztaroan, ibili izan zela ofizio ohoragarri hortan, ${ }^{167}$ gerthakari ketan kurrituz munduko bazter asko, ahantzi gabe Malagako Pertcheleak, E[r] riarango ${ }^{168}$ irlak, Sebillako Kompasa, Segobiako Azogejoa, Balentziako Olibadia, Granadako Arrondilla, Sa Lukarreko Zelhaya, Kordobako Potroa, Toledoko Mentattoak eta bertze asko toki zeinetan lanean ezarri baitzituen bere oinen zalhutasuna eta eskuen artechtasuna, makhur hainitz eginez, asko alhargunxaren ondotik ibiliz, zembait neskatcha garaituz, ${ }^{169}$ umezurtz batzu enganatuz, eta ${ }^{170}$ azkenaz goiti, hurran Espainia guziko tribunaletan ezagutaraziz bere burua. Gero erran zuen bildu zela azkenean bere gaztelu hartara non bizi baitzen bere onthasunetarik eta bertzeenetarik, ostatatuz zaldun ibildaun guziak, edozein iraulgi eta ${ }^{171}$ gra- $^{-}$ dotakoak, ekhartzen zioten amodio handiaren gatik eta harekin partitzekotan beren sosak berak erakusten zioten chede onaren ordainez. Mentazainak erran zion halaber etzuela haren gazteluak kaperarik non egin baitzezakeen harmetako beila, zaharra barrayatua zelakoz berri baten egiteko; bainan bazakiela dudagabe beila hura, behar orduan, nahi zen tokian egin zitakeela, eta ${ }^{172}$ heldu zen gaua beilan eman zezakeela jauregiko korral batean; biharamun goizean, Jainkoak nahi bazuen, eginen ${ }^{173}$ zituztela behar ziren zeremoniak, haletan non geldituko baitzen zaldun harmatua eta ${ }^{174}$ hain zaldun non ez baitzen ${ }^{175}$ izanen ahal zaldunagorik munduan.

Galdatu zion oraino hean bazuen dirurik. Don Kijotek ihardexi zuen etzuela ardit bat ere, zeren ez baitzuen liburuetan egundaino irakurtu zaldun ibildaunek sakelan izan zutela sosik. Horren gainean erran zion mentazainak, trompatzen zela, zeren liburuetan hori iskribatua ez den arren, heyen egileeri ${ }^{176}$ etzitzayotelakoz iduritu premia zela hain gauza garbiaz ${ }^{177}$ eta beharkituaz aiphatzea, nola baitzen dirua eta athorra churiak hartzea, etzela horren gatik uste izateko zaldunak halakorik gabe zabiltzala; eta hola segur eta egia garbitzat idukitzen ahal zuela, hambat liburuk aiphatzen eta ezagutarazten dituzten zaldun ibildaunek, zer gertha ere, berekin hartzen zituztela molxak hazkarki diruz sakhatuak, eta halaber athorrak eta kapatto bana erremedioz bethea izaten zituzten ukhaldien sendaraztekotzat, zeren hek gudukatzen

167. Ondoren tatxatuta: munduko bazter kurrituz

168. Ezin daiteke ongi irakurri kortxete artekoa, gainidatzia dagoelako.

169. Ondoren tatxatuta: zem

170. Ondoren tatxatuta: guzi

171. Ondoren tatxatuta: sortzetakoak

172. Ondoren tatxatuta: gau hura

173. Ondoren tatxatuta: zirela

174. Ondoren tatxatuta: munduan

175. Ondoren tatxatuta: munduan

176. Ondoren tatxatuta: ez baitzitzayoten

177. Ondoren tatxatuta: aiphatzea nola 
ziren mortu eta bazterretan ez baitzen atzematen zituzten sarraskien sen[d]atzailerik ${ }^{178}$, non etzuten adiskidetzat zembait charmari on, heyen laguntzera berehala ethorriko zena, hedoi batean airez aire erakhartzen zuelarik zembait andre gazte edo ñaño zeinak izanen baitzuen ampoila bat edo bertze bethea halako indarretako urez non inhar baten aski baitzen ordu berean sendatua gelditzeko sarraski eta ukhaldi guzietarik, egundaino batere izan ez balitz baino gehiago; bainan holako laguntza baten eskasean behialako zaldunek asmu on batentzat idukitzen zutela beren ezkutariek izan zezaten bethi nasaiki dirua eta premia diren bertze gauzak, hala-nola oihal lixa eta lotzeko erremedioak; eta gerthatzen zenean halako zaldunak ezkutaririk gabe (gutitan eta arras bakhan ikusten zen gauza) berek ekhartzen zutela guzia hain alportcha chumetan non doi doya baitziren ageri zaldiaren iphurdi konkorrean, bertze zerbait baliosagorik izan balitz bezala; ezik holako kasuz kampo alportchen erabiltze hori, etzen hambat onhexia izan zaldun ibildaunen artean. Aria hortaz, ematen zion konxeilu (eta hala behar bazen, manamendu ere, bere seme-biritchi ${ }^{179}$ hain laster izateko zuenari bezala) etzadiela gehiago bideari loth dirurik gab ez eta behar diren bertze puskak gabe, eta gutien ustean ikusiko zuela zein ongi kausituko zen heyen izateaz. Don Kijotek agindu zion zorrostasun guziarekin betheko zuela haren errana.

Horren gainean gauzak berehala chuchendu zituzten harmetako beila mentaren sahexean zen korral handi batean egiteko. Don Kijotek bildurik bere harmak oro ezarri zituen aska baten gainean putzu baten aldean; musu eman zion bere erredolari, eta lantza eskuan askaren aintzinean ateratu zen pasayetan patchada arin batekin. Bere harat-hunatak hasi zituenean, gaua erori hurrana zen. Mentazainak mentan ziren guzieri khondatu ziozkaten bere gizonaren erhokeria, harmetako beila eta nola igurikitzen zuen zaldun harmatua izatea. Espantiturik holako erhokiaren suerte harrigarriaz, goan ziren hari urrundik begiratzera, eta ikusten zuten aldi batzuz urhaxean astiki zabilala eta bertze aldi batzuz lantzaren gainean bermatua, begiak bere harmen gainetik higitu gabe luzez idukitzen. Gaua arras erori zen arren, ilhargiak hain ongi argitzen zuen, non ${ }^{180}$ erran baitzitakeen haren argia hain garbi zela nola iguzkiarena, eta ${ }^{181}$ orok arras onxa ikusten baitzuten zaldun aprendizak egiten zituen guziak. Hortan zirelarik, mentan geldituak ziren mandozainetarik bati gogora ethorri zitzayon bere mandoeri ura edatera ematea, eta hortako askaren gainetik khendu behar ziren don Kijoteren harmak. Hunek ikusirik hurbiltzen gizona, mintzo gora batez erran zion: «Nor nahi izan hadien, oi zaldun ausarta ${ }^{182}$ egundaino gerrian ezpata erabili duen zaldun ibildaun valentenaren harmen ukitzera heldu haizena, beha zak zer hari haizen eta berauk horiek uki, nahi ez baduk bizia utzi hire ausartziaren sari». Mandozainak hitz horietaz khechurik hartu gabe (eta hobe zukeen hartu balu, ezen etzukeen bere larruaz khechurik hartu beharko) aitzitik lothu zen uhaleri eta

178. Eskuizkribuan ez da ongi antzematen - $d$ - edo -b- den; dena den, sendagailuez ari direnez, $-d-$ izan behar du.

179. Hitz honetatik hasita -ari bezala tatxatua

180. Ondoren tatxatuta: guziek arras onxa ikusten baitzituzten zaldun aprendizak egiten zituenak oro

181. Ondoren tatxatuta: guziek

182. Ondoren tatxatuta: heldu haizena 
tresna guziak hara-harat arthiki zituen. Don Kijotek ikusi zuenean hori, zerura goititu zituen begiak, eta ${ }^{183}$ bere bihotza altchatuz (ageri izan zen bezala) bere andre Dulzinearen gana, erran zuen: «Ene laguntzera egizu, oi ene andrea, zure zerbitzari jarria den bihotz huni ${ }^{184}$ egiten zayon lehembiziko laido huntan; lehembiziko atheka tchar huntan ez biazatet huxik egin zure fagoriak eta languntzak. Hitz horiek eta bertze zembait holako erraten zituelarik, bere erredola utzirik, bi eskuzz goititu zuen lantza eta mandozainari burutik behera eman zion ukhaldi bat hain gaitza, non mustupilka igorri baitzuen mandozaina lurrerat eta hain planta tcharrean, non eman balio bertze bat, ez baitzitakeen bakar beharrik haren sendatzeko. Hori egin ondoan, bildu zituen bere harmak berriz itzuli zen pasayatzera hasi zenean bezain deskanxuz.

Handik aphur baten buruan, jakin gabe zer gerthatu zen (ezik mandozaina lurrean zagon ezagutzaz gabetua) haren lagunetarik bertze bat ethorri zen mandoeri uraren emateko gogo berean, eta harmen khentzen abiatu ${ }^{185}$ zenean askatik pocheluaren aladaratzeko, don Kijotek, hitz bat egin gabe, eta nihori fagorerik galdatu gabe, berriz ere utzirik ${ }^{186}$ erredola, goititu zuen lantza eta hura pusketan hauxi gabe, hiru zathi baino gehiago egin zuen bigarren mandozainaren buruaz, ezik ezarri zion lau pusketan. Harramantz hartara laster egin zuten mentan ziren guziek eta heyen artean mentazainak. Hori ikusirik, don Kijotek, musu eman zion bere erredolari, eta eskura harturik ezpata, erran zuen: «Oi edertasun guzien jabe zaren andrea, ene bihotz herbalduaren indar eta laguntza! orai da ordu itzul detzatzun zure handitasunaren begiak zure gathibu den zaldun hunen gainera, zeina hoin gerthakari gaitzaren iguri baitago. Hitz horiek erratearekin haren begiak ${ }^{187}$ haimbertze suz bethe ziren, non munduko mandozain guziek jazarri baliote ere, ez baitzuen urhax erdi batez gibelerat eginen. Lurrean joak zaudenen lagunek, hek planta hartan ikusirik, don Kijoteri ${ }^{188}$ urrundanik hasi ziren harrika. Hunek ahal bezain ongi bere burua erredolaz zaintzen zuen, eta etzen askatik urruntzera menturatzen, bere harmak ${ }^{189}$ begietarik ez uztea gatik. Mentazainak oihu egiten zuen utz zezaten geldirik, lehenago ere erran ziotela nola erhoa zen, eta erho bezala libro atherako zela hek oro hiltzen bazituen ere. Don Kijotek berriz, oihuak handiago zituen oraino, deitzen zituelarik traidore fedegabeak, jauregiko nausia zaldun desleyal gaizki ikasi bat zela, onhesten zituenaz geroztik halako ${ }^{190}$ egitateak zaldun ibildaunen alderat, eta ja izana ${ }^{191}$ izan balu zalduneriako ordena, erakuxiko ziola traidore bat zela «Bainan, zuek, zirtzil zikhinak, ez ${ }^{192}$ naiz zuen gatik niholaz khechatzen arthikatzue harriak, zatozte, hurbil zaitezte eta zuen ahal guziaz jazar

183. Ondoren tatxatuta: altch

184. Hitz honetatik hasita - $k$ jasaiteko duen tatxatua

185. Ondoren tatxatuta: zen

186. Ondoren tatxatuta: zuen

187. Ondoren tatxatuta: bethe

188. Hitz honetatik hasita tatxatuta: $-k$ hasi

189. Ondoren tatxatuta: gal beldurrez

190. Ondoren tatxatuta: planta

191. Hitzaren amaieran tatxatuta: - $n$

192. Ondoren tatxatuta: dut zuentzat erdeinua baizik 
diadazue eta ikusiko duzue zer sari altchatuko duten zuen ${ }^{193}$ erhokeriak eta ozartasunak». Hitz horiek erraten zituen halako ${ }^{194}$ larderia eta oldarretan, non izialdura handi bat sarrarazi baitzuen hari jasartzen zioten gizonen baithan. Aria hortaz eta mentazainaren solasok bildurik, baratu ziren harri etchatzetik. Don Kijotek utzi zituen kolpatuen altchatzera, eta harmen beilara itzuli zen ${ }^{195}$ hastean bezain deskanxu handitan eta khechu gutirekin.

Mentazainari etzaizkon eder iduritu gure zaldunaren dostetak, gogoan hartu zuen, laburrenetik egiteko berehala eman behar ziola zalduneriako ordena ondikozko hura, bertze zerbait estrapu gaichto gertha zadin baino lehen. Beraz don Kijoten aintzinera ethorririk bere burua garbitu zuen, gizon piltzar heyek haren jakingabean erabili zuten ausartziatik, ziolarik aski sari ona izan zuela heyen osarkeriak. Aintzinean bezala orduan berriz ${ }^{196}$ erran zion gaztelu hartan kaperarik etzela, bainan ${ }^{197}$ premiarik ere etzela gelditzen zenaren egiteko; zaldun harmatua gelditzeko egiteko zen guzia huntan zela, lepho zakian eta sorbalda gainean ematen diren bi ${ }^{198}$ kaskakoetan, ordenako zeremoniez zuen jakitatearen arabera, eta hori landa baten erdian egin zitakela; Harmetako beila ongi bethea zuela, hortako bi oren aski zirela eta harek bazituela lau baino gehiago emanik.

Don Kijotek oro sinhexi zituen; mentazainari erran zela hari obeditzera zagola eta gauzak ahalik laburrenetik akhaba zetzala, zeren bertze aldi batez bilhatzen bazuten eta ordukoz zaldun harmatua ayher baitzen gazteluan ez uztea jende bizirik, salbo harek nahiko zituenak, zeinek biziaz hari esker ${ }^{199}$ emateko baitzuten. Mezu horrek loxaturik, gazteluko nausiak berehala hartu zuen liburu bat zeintan ezartzen baitzituen mandozaineri ematen ziozkaten lastoa eta garagarra, eta don Kijoteren ganat ethorri zen muthiko batekin hunek argi moko bat eskuan, eta erran diren bi neskekin. Manatu zion belhaurika jar zadin; gero ${ }^{200}$ othoitz debot zembait bere liburutik irakurtzen balu bezala, artera eskua goititurik, lephoan eman zion kaska handi bat eta hartaz bertzalde berberaren ezpataz bigarren kaska on bat sorbaldan, bethi hortzen artean marmazikatuz othoitzean hari balitz bezala. Hori egin ondoan andretto hetarik bati manatu zion ezpata loth zezon gerrian eta hala egin zuen hainitz artechki eta gurbilki201 ezik etzen odol hotz guti behar ez lehertzeko irriz zeremoniako pondu bakotchean; bainan zaldun aprendizari orduco egiten ikusi ziozkaten balentriek igortzen zuten irria gibelerat. Ezpata gerrian tinkatzean gure andre gaichoak erran zion: «Jainkoak egin beza zure eskerra zaldun dohaxu eta zalde ezar bezo guduetan zoria». ${ }^{202}$ Don Kijotek galdegin zion hean zer zuen izena,

193. Ondoren tatxatuta: ausartzia zoroak

194. Ondoren tatxatuta: kalipu

195. Ondoren tatxatuta: hain

196. Ondoren tatxatuta: ere

197. Ondoren tatxatuta: egot

198. Ondoren tatxatuta: kachkotan

199. Ondoren tatxatuta: utziko baitzituen

200. Ondoren tatxatuta: irakurtzen $h$

201. Hitz honetatik hasita tatxatuta: -sunekin eta etzen

202. Ondoren tatxatuta: Humiltas 
jakitekotzat handik aizinerat hean nori ${ }^{203}$ zuen zor izan zuen fagorea, zeren parte eman gogo baitzion bere besoaren balentasunaz gerora bilduko zuen ohorean. Humiltasun handiz ihardexi zuen Tolosa zela deitzen, haren aita bilda zahar chuchentzaile eta Toledoko seme Chantcho Bienayaren chopetan bizi zena, eta nonnahi gertha zadin ${ }^{204}$ bethi haren zerbitzatuko ${ }^{205}$ izanen zela eta bere jaun eta nausitzat idukiko zuela. Don Kijotek erran zion berriz, handik aintzinerat haren amoreakatik egin ziozola fagore ezartzeaz dona bere izenaren aintzinean eta deit zadin dona Tolosa, eta harek agindu zion eginen zuela; Bertze neskak lothu zion ezproina eta harekin ere solas berxuak izan zituen nola ezpata ezartzailearekin. Galdegin zionean zer zuen izena, erran zuen Iharazainxa deitzen zutela, Antekerako iharazain prestu baten alaba zela. ${ }^{206}$ Don Kijotek othoiztu zuen hura ere ezar zezan dona eta deith zadin Dona Molinera, eta eskeini ziozkan berriz bere zerbitzu eta fagoreak. Tarrapataka eta harramaskan egin zuen ordoan han egundaino ikusi etziren zeremonia horiek, don Kijote hurrandua zagon bere burua zaldi gainean ikusi nahiz eta gerthakari ketara ilkhi beharrez. Berehala zelatu zuen Errozinante eta jausi egin zion gainera; eta besarkatzean bere ostatatzailea, erraten ziozkalarik nihork ez bezalako solas batzu, esker emanez zeren zaldun harmatu zuen, haimbertzetaraino non heyen chuchenki ekhartzea hemen ezin den gauza baita. Mentazainak, hura lehen bai lehen mentatik kampo ikustea gatik, haren hitzeri ihardexi zuen ez solas gutiago ederrez bainan laburragoz, eta ostatu saririk galdatu gabe yoatera utzi zuen Jainkoarekin.

203. Ondoren tatxatuta: zor

204. Ondoren tatxatuta: gogotik

205. Ondoren tatxatuta: zuela

206. Ondoren tatxatuta: Huni ere 


\section{Bibliografia}

Apraiz, J. 1905. Donkituera umill euskalduna Cervantes-eri opatua Manchako don Quijote, seme argi ta ospatsua agertu zanetik irugarren eunki-urrunean. Vitoria-Gasteiz.

Dodgson, E.S. 1904. Essai de traduction basque de Don Quichotte sur la demande du Coronel Espagnol. Antze handitako Aitoren seme Don Kichote Mantchakoaren gerthakariak Don Miguel de Cervantes Saavedrak Erdaraz ezarriak Duvoisin Kapitainak Eskararat itzuliak. Ernest Seitz: Biarritz.

Haristoy, J. 1895. Le Capitaine Duvoisin et ses travaux. Euskal-Erria 32, 213-217, 273-276, 365-372, 401-405.

Mitxelena, K. 1988. Historia de la literatura vasca. Erein: Donostia.

Torres Santo Domingo, M. 2005. "El primer facsímil del Quijote: la aventura editorial de Francisco López Fabra (1871-1879)”. In Alía Miranda, F. / A. L. Galán Gall / R. Rodriguez Álvarez (coord.). El Quijote en las bibliotecas universitarias españolas. Universidad de Castilla-La Mancha, 73-87.

Urkizu, P. 2004. Traducciones vascas del Quijote y de otras obras cervantinas. Revista de lenguas y literaturas catalana, gallega y vasca 10, 205-210.

Zumuarregui, G. 1923. “"El Quijote” en vascuence”. El Pueblo Vasco. Diario Independiente. Donostia. (Maiatzaren leko alea) 